\title{
Effect of Solar Radiation on Module Photovoltaics 100 Wp With Variation of Module Slope Angle
}

\author{
Azriyenni Azhari Zakri*1 ${ }^{1}$, Iswadi Hasyim Rosma ${ }^{2}$, Dohardo P H Simanullang ${ }^{3}$ \\ Department of Electronical Engineering, Faculty of Engineering, Universitas Riau, Indonesia
}

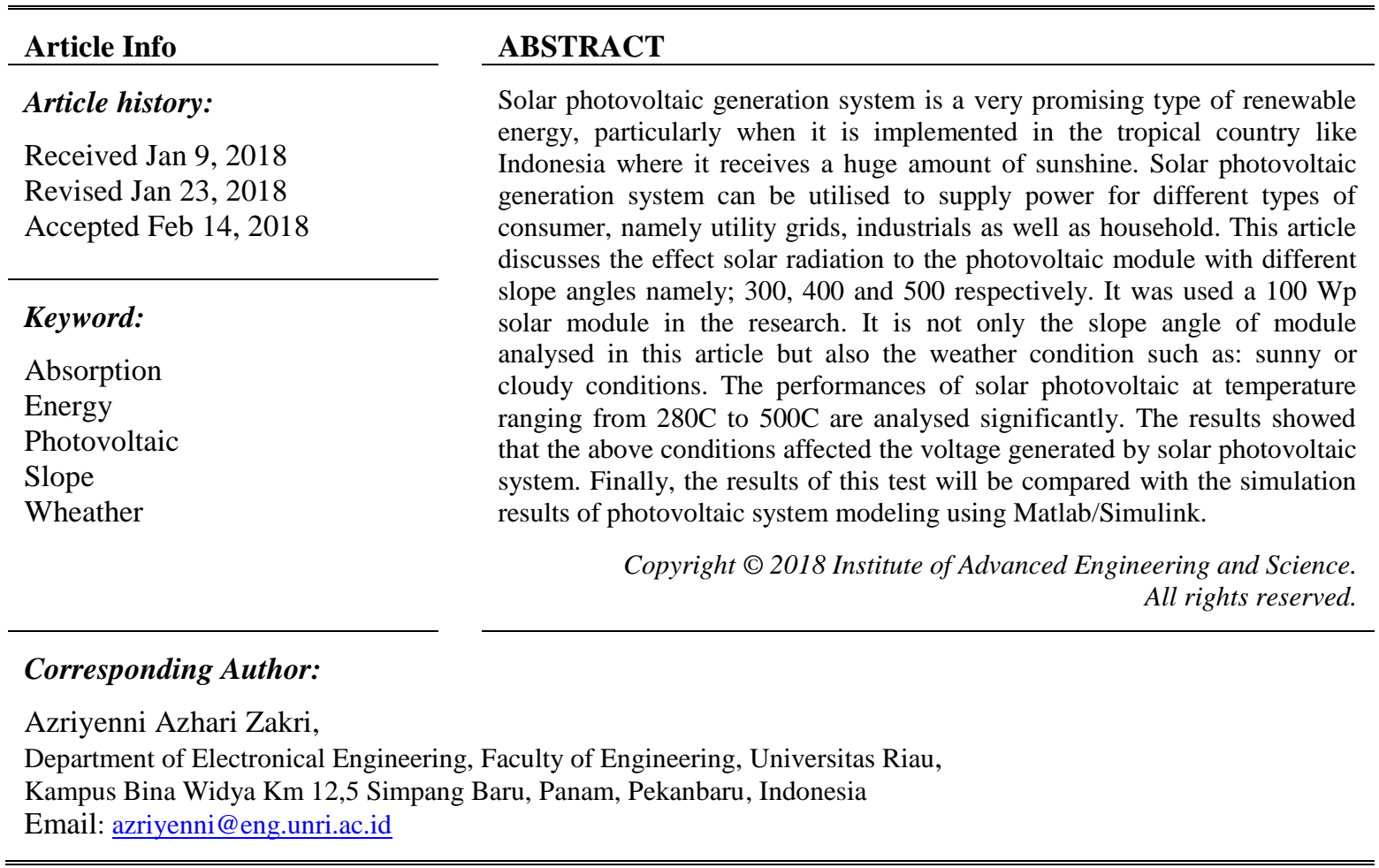

\section{INTRODUCTION}

When integrating solar photovoltaic based renewable energy, a number of problems will arise such as prediction of photovoltaic configuration and battery size, prediction of energy consumption, maximum power system and photovoltaic system performance analysis. Initial stage of solar photovoltaic systems must consider a number of parameters, namely: size, identification and simulation applications. This article will introduce solar radiation model based on weather forecasting system. It produces short-term photovoltaic output predictions from the meteorological department data. The output of solar radiation is a prediction model of photovoltaic power output and computation speed algorithm [1].

Mohamed A has proposed the installation of photovoltaic systems requiring an estimation of solar radiation. The size of the photovoltaic module represents the characteristics of $\mathrm{V}$ and $\mathrm{I}$ in which the model predicted. Artificial Neural Network Method (ANN) has applied variable parameters controlled and uncontrolled input by way of learning. An advantage of using ANN is the ability to handle complex systems with many parameters [2]. Ramenah has proposed a solar cell based power system sensitivity to temperature. In real conditions, photovoltaic modules operate at temperatures influenced by random solar radiation. Photovoltaic systems are on variable weather basis. He reviewed the experimental influence of changes in temperature relations and solar radiation on the performance of photovoltaic systems. The experimental approach leads to the expression of the solar energy transfer process model to electrical energy [3].

Akos Baldauf has developed renewable energy for residential using photovoltaic systems. In controlling the production of electrical power to the grid system using Demand Side Management (DSM) techniques. The DSM technique aims to reduce customer costs and power losses on the grid. A scheduling algorithm is implemented using consumer historical data [4]. 
The aim of this research is to evaluate the performance of a $100 \mathrm{Wp}$ at different temperature. Furthermore, the modeling of photovoltaic system is using Matlab/Simulink and will simulate the radiation values against different temperatures. These two results are analysed by the effect of solar absorption on photovoltaic module.

\subsection{Solar radiation}

Solar energy in electromagnetic radiation emitted to the earth from sunlight. Solar energy consists of photons or particles of solar energy converted into electrical energy. The solar energy arriving at the surface of the earth called a global solar radiation measured by power density at the surface of the receiving area. The average value of earth's solar radiation is $1,353 \mathrm{~W} / \mathrm{m} 2$ characterised in a solar constant. The intensity of solar radiation has been affected by the cycle time of the earth's rotation. Weather conditions include cloud quality and quantity. The intensity of solar radiation in Indonesia lasts $4-5$ hours per day $[5,6]$.

The energy of solar radiation is located in the form of light and electromagnetic waves. The solar radiation spectrum itself consists of two, namely: short wavy rays. Any changes in the distance of the earth and the sun give rise to variations on the reception of solar energy. The intensity of solar radiation, i.e the size of angle of the sun's rays on the surface of the earth. The amount received is precisely proportional to the angle. Rays with oblique angles come less energizing on the earth's surface, because radiation is scattered on very wide surfaces through the atmospheric layers. The rays are angles that are perpendicular further than if the rays with angles come perpendicular. The amount received is precisely proportional to the angular magnitude of the incident angle. The rays atmosphere will partly be adsorbed by gas, dust and water vapor. It will be reflected back and emitted. The rest forwarded to the surface of the earth. Air, moisture and dust will absorb, diffuse, and reflect solar radiation. Clouds absorb most of the radiation at different wavelengths and the radiation situation more complex. In addition, solar radiation is a lot of reflection between cloud and soil for the presence of clouds. This situation will have a significant impact on changes in illumination at the base of the atmosphere. The prediction of solar power we need is information obtained from the meteorology department could not be obtained directly from the meteorology department $[7,8]$.

For more details, meteorological data such as direct and disperse solar radiation, ambient temperature, humidity and speed may be indispensable for the completeness of the data [9]. The PV generator connected to the grid provides with supplying power to low the voltage distribution network will be the current and voltage unbalance. Non linear characteristic panels solar cell based on various environmental conditions such as temperature and solar radiation [10]. The performance of PV systems According to operate conditions as well as solar cells and the quality of array design. The output voltage, current and power of the PV arrangement vary as a solar function level of irradiation, temperature and load current. Hence, the effect of these three numbers must be observed in the design of PV arrays so that any changes in temperature and sun irradiation levels should not affect the output of the PV array to the load. The PV model is also designed in this paper with a circuit based model to be used with Simulink [11].

\section{RESEARCH METHOD}

Photovoltaic technology is designed to capture solar energy resulting in higher photovoltaic output voltage than battery voltage. The photovoltaic output voltage adjusted by using Solar Charge Controller (SCC) function as a voltage regulator to the battery. The initial designing can be made to distribute electrical energy according to the required energy. In this research will be tested solar cell with capacity $100 \mathrm{Wp}$ (Watt-peak). It will do a simulation of solar cell based on Matlab/Simulink. The capacity observed the effect of solar radiation, temperature, voltage and current photovoltaic. This paper includes the modeling of photovoltaic module as well as the photovoltaic array. The modeling is built on mathematical expression which was found from the equivalent circuit of a solar cell. The effect of parameter variation on output of a photovoltaic module is thought to be.

The aim of this research is evaluated and simulated using Matlab/Simulink. In this article, it also shows in the performance of current versus voltage generated from the absorption of solar cells. The evaluation was conducted from 08.00 to 17.00 WIB with variation of photovoltaic module slope angles, namely: $30^{\circ}, 40^{\circ}$, and $50^{\circ}$. The testing procedures are presented as follows.

i. Measuring the absorption of solar radiation on photovoltaic.

ii. Measuring temperature on photovoltaic module.

iii. Measuring the voltage across the photovoltaic module.

iv. Measuring the current on photovoltaic module. 
Table 1. Specification of SP-100-P36 Photovoltaic Module

\begin{tabular}{cc}
\hline Electrical Parameter & Photovoltaic Module \\
\hline Nominal power output & $100 \mathrm{~W}$ \\
Voltage open circuit (Voc) & $22.6 \mathrm{~V}$ \\
Current short circuit (Isc) & $6.09 \mathrm{~A}$ \\
Voltage at Pmax & $17.6 \mathrm{~V}$ \\
Current at Pmax & $5.69 \mathrm{~A}$ \\
Temperature & $-45 \square \mathrm{C} \pm 80 \square \mathrm{C}$ \\
No. of series connected cell & 36 \\
\hline
\end{tabular}

Furthermore, this research is further conduction the modeling design of photovoltaic system using Matlab/Simulink. This model of $100 \mathrm{Wp}$ is shown in Figure 1. Figure 1 also shows a simulation with solar radiation input value (Ir) and temperature $\mathrm{FV}(\mathrm{Tfv})$. This model is subsequently simulated comprehensively with solar radiation variations of $100 \mathrm{~W} / \mathrm{m} 2$ to $1000 \mathrm{~W} / \mathrm{m}^{2}$.

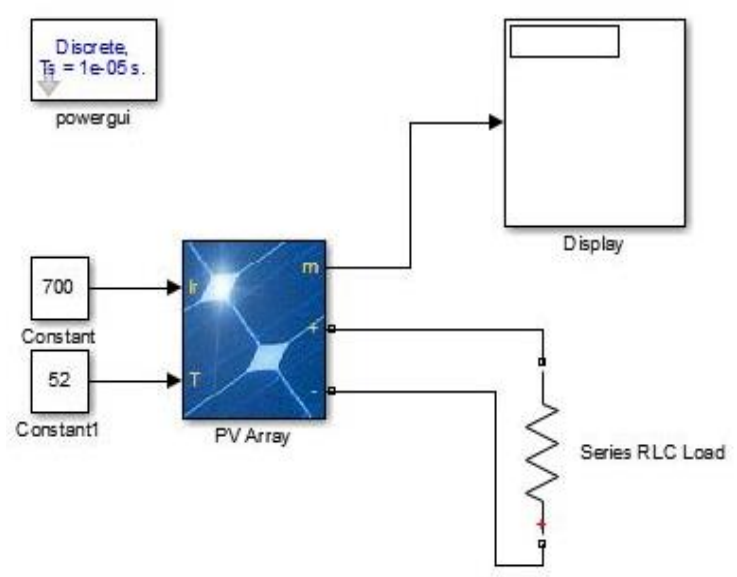

Figure 1. Photovoltaic modeling via Matlab/Simulink

\section{RESULTS AND ANALYSIS}

The test results of the solar radiation absorption system on the photovoltaic module expressed in graphical form illustrated in Figure 2 to Figure 4.Figure 2 shows the graph of solar radiation absorption (Ir) when solar panel slope angle at $30^{\circ}$. The solar radiation from $100 \mathrm{~W} / \mathrm{m}^{2}$ to $1000 \mathrm{~W} / \mathrm{m}^{2}$ was used in the simulation. The measured temperature of the photovoltaic module was between $28^{\circ} \mathrm{C}$ to $50^{\circ} \mathrm{C}$.

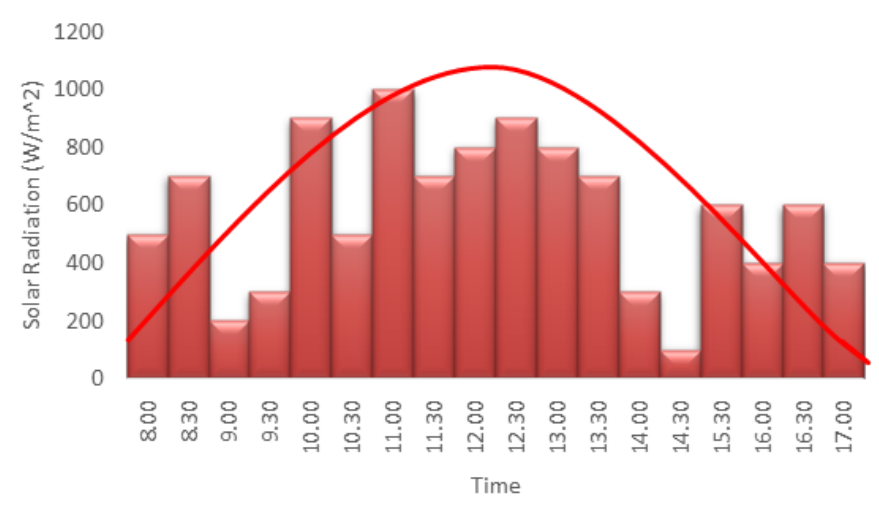

Figure 2. Graph of solar radiation absorption at $30^{\circ}$ angle 
Figure 3 shows a graph of solar radiation absorption $\left(\mathrm{I}_{\mathrm{r}}\right)$ against time when the solar module slope angle at $40^{\circ}$. The solar radiation tested $100 \mathrm{~W} / \mathrm{m}^{2}$ to $1000 \mathrm{~W} / \mathrm{m}^{2}$. The temperature of the photovoltaic module was from $28^{\circ} \mathrm{C}$ to $50^{\circ} \mathrm{C}$.

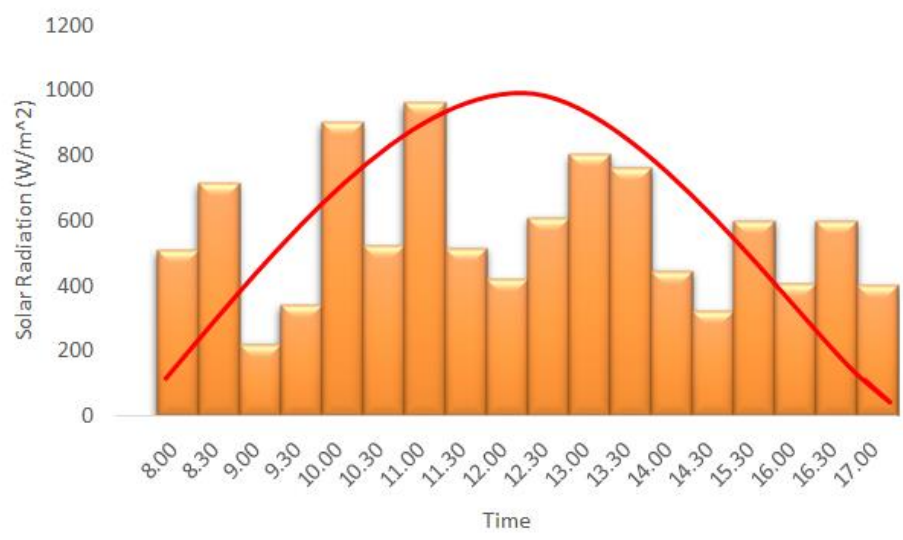

Figure 3. Graph of solar radiation absorption at a slope the angle of $40^{\circ}$

Figure 4 shows the characteristic of solar radiation absorption (Ir) test against time with the slope angle of the photovoltaic module at $50^{\circ}$. Range of solar radiation is form $100 \mathrm{~W} / \mathrm{m}^{2}$ to $1000 \mathrm{~W} / \mathrm{m}^{2}$. The temperature of the photovoltaic module was from $28^{\circ} \mathrm{C}$ to $50^{\circ} \mathrm{C}$.

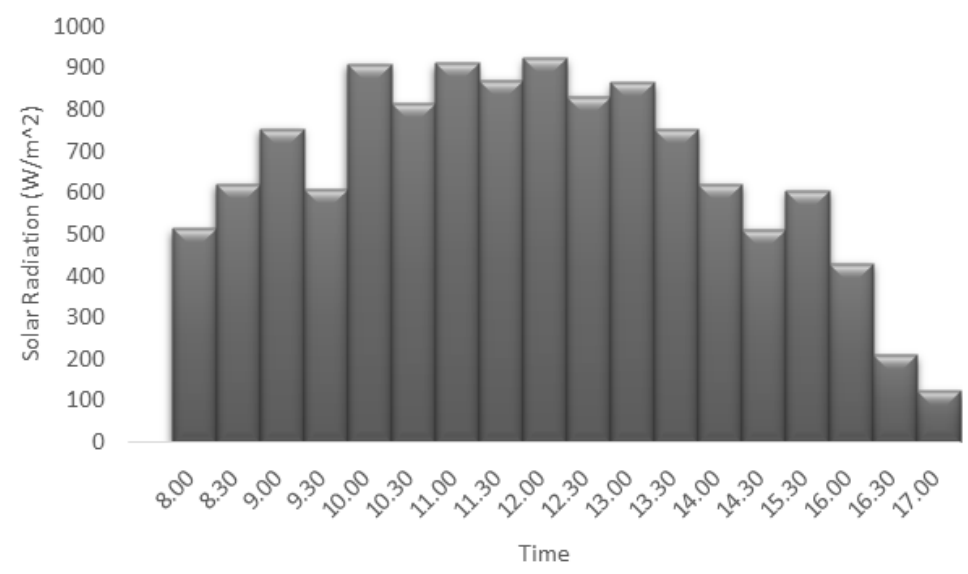

Figure 4. Graph of solar radiation absorption at a slope of the angle of $50^{\circ}$

Figure 5 describe the solar radiation absorption (Ir) by using Matlab/Simulink model. The solar radiation between $100 \mathrm{~W} / \mathrm{m}^{2}$ to $1000 \mathrm{~W} / \mathrm{m}^{2}$ were used as an input. Furthermore, the temperature value from $30^{\circ} \mathrm{C}$ to $47^{\circ} \mathrm{C}$ were also considered as input data. This simulation was run until 26 iterations. The results of the graph test of Figure 2 until Figure 4, the analysis of the test graph is close to the ideal graph. Although, the test result graph is not exactly the same, but it has approached the trend of the ideal graph. This is due to significant weather changes during the test. The graph simulation result of Figure 5, this graph analysis approached to the trend ideal graph. The value of solar radiation input in the model can be adjusted according to the desired. Then, to predict the amount of solar production, it is necessary to predict the solar radiation as described in Figure 5. This Figure illustrates the predicted solar radiation based on Matlab/Simulink. 


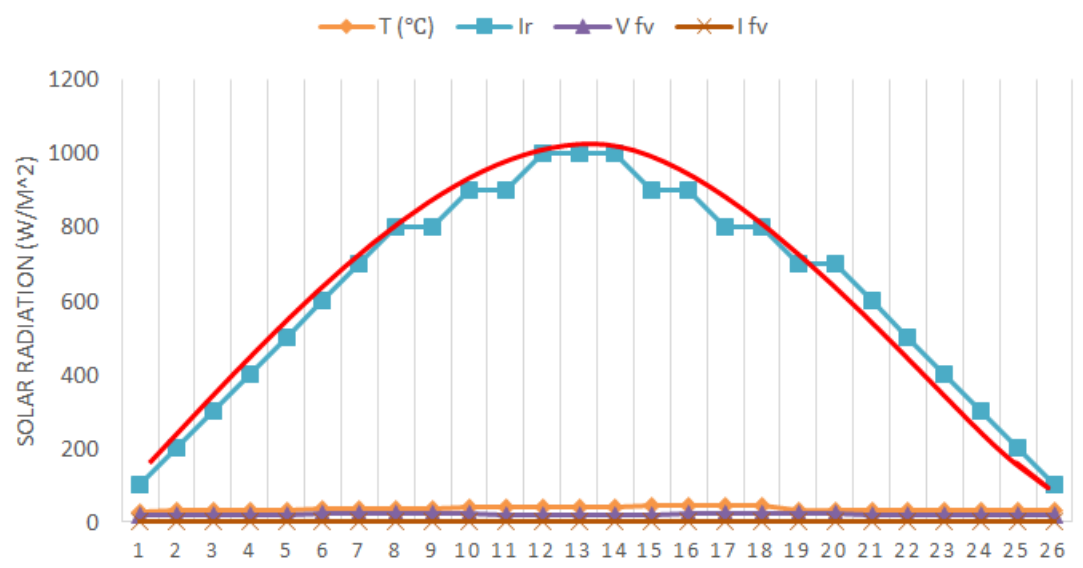

Figure 5. Graph of solar radiation absorption for simulation of photovoltaic systems

Figure 6 shows a graph of the results of the test results and simulation results of solar radiation absorption $\left(I_{r}\right)$ and power $(P)$ produced by photovoltaic. The power output of the simulation is better than the test result. This is because the weather at the time of testing is not stable, due to the weather that suddenly overcast and consequently the absorbed current becomes unstable.

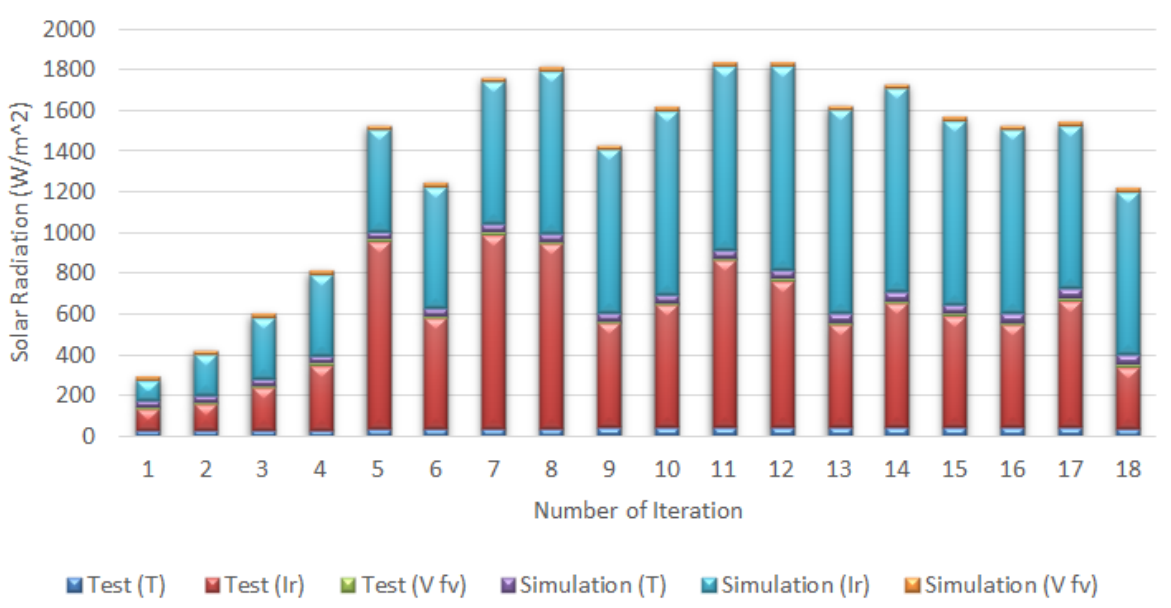

Figure 6. Graph of the voltage comparison between test and simulation results

Figure 7 shows the graph of error calculation result between test result and simulation result for a photovoltaic system and illustrates the process of solar radiation with the generated power. In this chart, the percentage error value of the photovoltaic current $\left(\mathrm{I}_{\mathrm{fv}}\right)$ is $2 \%$ sharp, and it shows the error percentage value of photovoltaic voltage $\left(\mathrm{V}_{\mathrm{fv}}\right)$ is not more than $1.5 \%$. Furthermore, we observe the percentage value of solar radiation $\left(\mathrm{I}_{\mathrm{r}}\right)$ has given a fairly good error value of $1.2 \%$. And finally, we have observed the error percentage value for photovoltaic temperature $(\mathrm{T})$ has given the best value with no more than $0.5 \%$. 


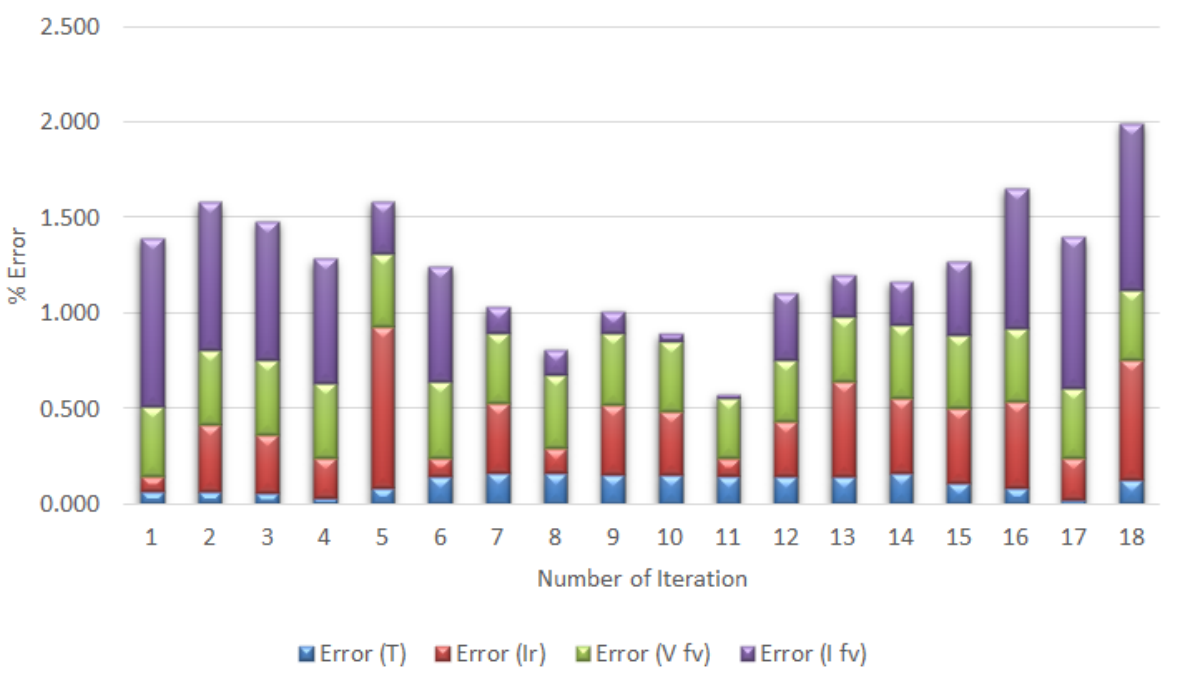

Figure 7. The comparison of error percentage

In this section, it is explained the results of research and at the same time is given the comprehensive discussion. The results can be presented in Figures 7, graphs, Tables and others that make the reader understand easily. The discussion can be made in several sub-chapters.

Table 2 shows comparison between the test results and simulation results of a $100 \mathrm{Wp}$ photovoltaic system. The tests were conducted on the temperature from $28^{\circ} \mathrm{C}$ to $50^{\circ} \mathrm{C}$, and the measured radiation results of $108 \mathrm{~W} / \mathrm{m}^{2}$ to $951 \mathrm{~W} / \mathrm{m}^{2}$. Furthermore, for the simulation results, the photovoltaic temperature values from $30^{\circ} \mathrm{C}$ to $47^{\circ} \mathrm{C}$, and input radiation values ranging from $100 \mathrm{~W} / \mathrm{m}^{2}$ to $1000 \mathrm{~W} / \mathrm{m}^{2}$.

Table 2. Results of Testing and Simulation of Photovoltaic Systems

\begin{tabular}{cccccccc}
\hline \multicolumn{3}{c}{ Test } & \multicolumn{5}{c}{ Simulation } \\
\hline $\mathrm{T}\left({ }^{\circ} \mathrm{C}\right)$ & $\mathrm{I}_{\mathrm{r}}\left(\mathrm{W} / \mathrm{m}^{2}\right)$ & $\mathrm{V}_{\mathrm{fv}}(\mathrm{V})$ & $\mathrm{I}_{\mathrm{fv}}(\mathrm{A})$ & $\mathrm{T}\left({ }^{\circ} \mathrm{C}\right)$ & $\mathrm{I}_{\mathrm{r}}\left(\mathrm{W} / \mathrm{m}^{2}\right)$ & $\mathrm{V}_{\mathrm{fv}}(\mathrm{V})$ & $\mathrm{I}_{\mathrm{fv}}(\mathrm{A})$ \\
28 & 108 & 12.6 & 0.4 & 30 & 100 & 19.81 & 3.439 \\
29 & 129 & 12.6 & 0.8 & 31 & 200 & 20.54 & 3.566 \\
30 & 210 & 12.7 & 1 & 32 & 300 & 20.95 & 3.638 \\
34 & 315 & 12.9 & 1.3 & 33 & 400 & 21.24 & 3.688 \\
37 & 921 & 13.3 & 2.7 & 34 & 500 & 21.46 & 3.726 \\
40 & 541 & 12.9 & 1.5 & 35 & 600 & 21.64 & 3.757 \\
42 & 951 & 13.7 & 4.3 & 36 & 700 & 21.79 & 3.783 \\
43 & 903 & 13.5 & 3.3 & 37 & 800 & 21.92 & 3.806 \\
44 & 513 & 13.7 & 4.3 & 38 & 800 & 22.04 & 3.862 \\
45 & 601 & 14 & 4 & 39 & 900 & 22.14 & 3.843 \\
46 & 820 & 13.5 & 3.5 & 40 & 900 & 19.72 & 3.424 \\
47 & 717 & 13.8 & 4.8 & 41 & 1000 & 20.46 & 3.551 \\
48 & 501 & 13.7 & 4.4 & 42 & 1000 & 20.87 & 3.623 \\
50 & 604 & 13.1 & 4.5 & 43 & 1000 & 21.16 & 3.673 \\
49 & 546 & 13.2 & 2.3 & 44 & 900 & 21.38 & 3.711 \\
49 & 499 & 13.2 & 1 & 45 & 900 & 21.56 & 3.743 \\
45 & 623 & 13.7 & 0.8 & 46 & 800 & 21.71 & 3.769 \\
41 & 301 & 13.7 & 0.5 & 47 & 800 & 21.84 & 3.791 \\
\hline
\end{tabular}

Table 3 shows the calculation of error values of test results and simulation results for photovoltaic systems. This table 2, for temperature (T) the error value is not more than $0.163 \%$. Solar radiation (Ir) found the highest error value $0.624 \%$. Voltage (Vfv) generated the highest error value $0.404 \%$. Finally, the current (Ifv) is found to be an error value not exceeding $0.884 \%$.

The results of this study are capable of predicting the voltage and current of photovoltaic output to produce system photovoltaic characteristics to be installed at selected locations. These results can estimate daily electricity production by determining the performance of a $100 \mathrm{Wp}$ photovoltaic systems. Direct measurements are observed with significantly different weather every day. Furthermore, the results of these direct measurements are validated with simulated models for predicting and estimating solar radiation in 
varying angles of different photovoltaic panels. Modeling and characteristics of photovoltaic generator system make it possible to confirm that the slope of angle of $50^{\circ}$ provides good absorption of value ideal solar radiation.

Table 3. Result of Error Percentage for Photovoltaic System

\begin{tabular}{cccc}
\hline \multicolumn{4}{c}{ Error $\mathbf{( \% )}$} \\
\hline $\mathrm{T}$ & $\mathrm{I}_{\mathrm{r}}$ & $\mathrm{V}_{\mathrm{fv}}$ & $\mathrm{I}_{\mathrm{fv}}$ \\
\hline 0.067 & 0.080 & 0.364 & 0.884 \\
0.065 & 0.355 & 0.387 & 0.776 \\
0.063 & 0.300 & 0.394 & 0.725 \\
0.030 & 0.213 & 0.393 & 0.648 \\
0.088 & 0.842 & 0.380 & 0.275 \\
0.143 & 0.098 & 0.404 & 0.601 \\
0.167 & 0.359 & 0.371 & 0.137 \\
0.162 & 0.129 & 0.384 & 0.133 \\
0.158 & 0.359 & 0.378 & 0.113 \\
0.154 & 0.332 & 0.368 & 0.041 \\
0.150 & 0.089 & 0.315 & 0.022 \\
0.146 & 0.283 & 0.326 & 0.352 \\
0.143 & 0.499 & 0.344 & 0.214 \\
0.163 & 0.396 & 0.381 & 0.225 \\
0.114 & 0.393 & 0.383 & 0.380 \\
0.089 & 0.446 & 0.388 & 0.733 \\
0.022 & 0.221 & 0.369 & 0.788 \\
0.128 & 0.624 & 0.373 & 0.868 \\
\hline
\end{tabular}

There are several differences from the results of solar radiation absorption testing conducted by Nurhalim et.al at the temperature interval starting at $24^{\circ} \mathrm{C}$ and $36^{\circ} \mathrm{C}$. The Solar module testing was performed at $08.00 \mathrm{AM}-05.00 \mathrm{PM}$ at temperatures starting from $28^{\circ} \mathrm{C}$ to $50^{\circ} \mathrm{C}$. The extreme weather that occurs causes the process of absorption of solar radiation. The observed differences at significant temperatures, this has the effect of fluctuations occurring on the absorption of radiation to the solar module. This study provides an improvement from previous research that observed the process of solar radiation absorption for the slope of panel angles varied. Finally, this study contributes to the testing of solar cells for the slope of different panel angles. All data will be saved as a data base that can be used as a reference for solar cell design in the future.

\section{CONCLUSION}

The results of this study have presented the results of direct testing and simulation of $100 \mathrm{Wp}$ photovoltaic system modeling. The test results for photovoltaic module elevation have been performed at different angles. Corner angle elevation has been tested; $30^{\circ}, 40^{\circ}$, and $50^{\circ}$. The test results of these three elevation angles are not much different. The results of the test and simulation have given the characteristics of the solar radiation absorption system, the voltage characteristics of the photovoltaic system to $100 \mathrm{Wp}$. Photovoltaic system modeling design that has been designed using software, so it can be a reference for designing the prototype with the capacity we want. Direct testing has been done by observing in different weather. It has been validated with simulation results for the prediction and estimation of solar radiation. The characteristics of the photovoltaic generator system have been confirmed that the slope of angle $50^{\circ}$ provides superior absorption of near ideal solar radiation.

\section{REFERENCES}

[1] Meijun Lin, Z.W., Yang Liu, Meng Chen, Fanyao Meng, Power Prediction Model of Grid Connected Photovoltaic and Power Flow Analysis, in IEEE. 2012.

[2] Mohamed Abdelmoula, M., Bruno Robert. Design and Modeling of a Stand alone Photovoltaic System. in International conference on Sciences and Techniques of Automatic control \& computer engineering 2014. Hammamet, Tunisia: IEEE.

[3] H. Ramenah, C.T., L. Cicero, Toward a prediction of the photovoltaic based power production from Experimental Thermal modeling, in ITEC Asia-Pacific. 2014.

[4] Baldauf, A., A smart home demand-side management system considering solar photovoltaic generation, IEEE, Editor. 2015 .

[5] Takuro Tsuji, A.H., Satoshi Matsumoto, A Stand-Alone Power Supply System Using Single Photovoltaic Cell with Maximum Power Point Tracking. 2014. 
[6] Boucetta Abd Allah, L.D., Control of Power and Voltage of Solar Grid Connected. International Journal of Electrical and Computer Engineering, 2016. 6(1): p. 26-33.

[7] Wikipedia Radiasi Matahari. 2017.

[8] Mohamed Louzazni, E.H.A., Hanane Yatimi, Modeling and Simulation of A Solar Power Source for a Clean Energy without Pollution. International Journal of Electrical and Computer Engineering (IJECE), 2013. 3(4): p. 568-576.

[9] Mustapha Elyaqouti, L.B., Ahmed Ihlal, Modelling and Predicting of the Characteristics of a Photovoltaic Generator on a Horizontal and Tilted Surface. International Journal of Electrical and Computer Engineering (IJECE), 2016. 6(6): p. 2557 2576

[10] Amirullah, A.K., Power Quality Enhancement of Integration Photovoltaic Generator to Grid under Variable Solar Irradiance Level using MPPT-Fuzzy. International Journal of Electrical and Computer Engineering (IJECE), 2016. 6(6): p. 2629 2642.

[11] J. Surya Kumari, C.S.B., Mathematical Modeling and Simulation of Photovoltaic Cell using Matlab-Simulink Environment. International Journal of Electrical and Computer Engineering (IJECE), 2012. 2(1): p. 26 34.

[12] Nurhalim, Azriyenni, Firdaus and Syaiful Bahri, Solar Electric Power Generator (SEPG) as a Solution for Peak Load in Household Sector as Energy Conservation System: A Case Study in Pekanbaru City of Indonesia, 2012. IEEE. 